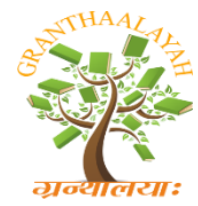
\author{
GRANTHAALAYAH \\ A knowledge Repository
}

INTERNATIONAL JOURNAL OF RESEARCH -

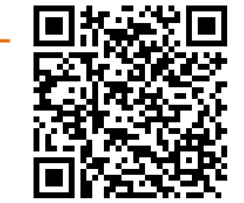

Science

\title{
A CLINICAL STUDY TO EVALUATE THE EFFICACY OF KASHMARYADI OIL (TRADITIONAL FORMULA) IN THE MANAGEMENT OF KHALITYA
}

\author{
Pramodani MPN ${ }^{* 1}$, Peiris KPP ${ }^{2}$ \\ ${ }^{*}$ Department of Cikitsa, Gampaha Wickramarachchi Ayurveda Institute, University of \\ Kelaniya, Yakkala, Sri Lanka \\ ${ }^{2}$ Department of Shalya Shalakya, Gampaha Wickramarachchi Ayurveda Institute, University of \\ Kelaniya, Yakkala, Sri Lanka \\ DOI: https://doi.org/10.29121/granthaalayah.v5.i1.2017.1729

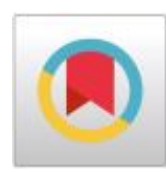

\begin{abstract}
Hair loss is a dermatological disorder that has been recognized for more than 2000 years. It is common throughout the world and has been estimated to affect nearly $2 \%$ of the world's population. Apart from metabolic and hereditary causes, alopecia has been observed as a major side effect of anticancer, immunosuppressant and many others drug treatments. To solve the above query and to find out a promising remedy, the present study has been undertaken.

In Ayurvedic approach, loss of hair is coined out as in term of Khalitya under the broad heading of Shiroroga. For this Moordha Taila (Shiroabyanga) is the management and when is done with Taila which is medicated by hair growing drugs is more efficacious. So in present study Kashmaryadi oil advocated in traditional medicine that has Keshya properties has been selected.

Sixty patients were selected; they were examined and recorded their history in the performa that prepared including all the necessary aspects of Ayurveda and modern medical science. The patients were advised to give gentle massage to the scalp covering whole area with hair oil at night and rinse it in the morning.

The clinical condition was assessed before, after two weeks, after four weeks and after follow up period. Using grading system assessed signs and symptoms. Hair fall, Darunaka, Kandu, Kesha Rukshatwa, Kesha Katinya, Kesha Tanutwa, Kesha Bhoomi Daha, Kesha Bhoomi Durganda were assessed and observed the significant reduction of symptoms. Considering the total treatment assessment there were $41.67 \%$ complete remission, $30 \%$ marked improvement, $16.67 \%$ moderate improvement, $8.33 \%$ mild improvement and $3.33 \%$ unchanged. No adverse reaction reported in this study period.

It is concluded that Kashmaryadi oil is very effective in the treatment of hair loss.
\end{abstract}

Keywords: Hair Loss; Khalitya; Hair Oil. 
Cite This Article: Pramodani MPN, and Peiris KPP. (2017). "A CLINICAL STUDY TO EVALUATE THE EFFICACY OF KASHMARYADI OIL (TRADITIONAL FORMULA) IN THE MANAGEMENT OF KHALITYA.” International Journal of Research Granthaalayah, 5(1), 137-143. https://doi.org/10.29121/granthaalayah.v5.i1.2017.1729.

\section{Introduction}

In Ayurvedic texts there are four types of Ayu. Among these Sukhayu is most important. Sukhayu deals with life without physical and mental disorders having qualities like Bala,Virya,Parakrama and Soundarya.

The concept of beauty (Soundarya) is gaining more and more attention globally and hair plays an important role in it, as it has been said that hair is a barometer of one's beauty. Healthy, beautiful, long and attractive hairs add charm to the personality. It adds a great aesthetic value and it is the crowning glory of any person. Not only has that hair had protective function also. Head hair protects the scalp against the burning sun and helps hold in body heat. Hair gives insulation, protection from external factors friction buffer, differentiation and beautification and redirect sweat and water.

Therefore to keep the healthy hairs in healthy state is entirely the duty of human beings, because just like face, hair is also a mirror of healthy state of the body.

Even thousand years ago, in Ayurvedic literature, so many types of daily regimens for hair care have been described in the chapter of Dinacharya and Ritucharya, which includes some procedures like Moordha Taila, Nasya, Snana, Rasayana sevana etc. ${ }^{(1)}$

While, in 21st century with modernization in each and every walk of life, a person has neither time to think and act for healthy life nor to follow the proper Dinacharya especially Moordha Taila and Ritucharya.

Hair loss is silent but devasting problem which may occur to a healthy person also. It has been regarded as geriatric physiological phenomena, generally after the mid-forties. Early hair fall has been attributed to be the result of varied factors like hormonal imbalance, faulty hair care, pollution etc. To solve the above query and to find out a promising remedy the present study has been undertaken.

In Ayurvedic approach, loss of hair is coined out as in term of 'Khalitya' under the broad heading of Shiroroga ${ }^{[1]}$ For these, Moordha Taila (Shiroabyanga) is the choice of management and when is done with that Taila which is medicated by hair growing drugs, is more efficacious. Importance of Shiroabhyanga is well accepted in the treatment of khalitya. Khalitya is a disease with Vata-pitta dominancy. Increased Pitta dosha along with Vatadosha at the root of hair follicle causes hair fall and at the same time Kaphadosha with Raktdosha blocks the roots of hair follicle which results into Khalitya. ${ }^{[2]}$ 
So in this present study Kashmaryadi oil advocated in traditional treatment for Khalitya has been selected. These are signs of early ageing process and to check it a Rasayana and Keshya drug combination has been chosen for the present study.

\section{Aims and Objectives}

- The present study has been undertaken with the following aim and objective.

- To assess the effectiveness of Kashmaryadi oil in the management of Kalitya.

\section{Materials and Methods}

Sixty patients attending for clinics in Gampaha Wickramarachchi Ayurveda Institute Yakkala, Sri Lanka fulfilling the criteria of the disease were selected randomly irrespective of their gender, religion etc.

\section{Inclusion Criteria:}

Patients presenting with the clinical features of Kalithya (Falling hair) described as per Ayurveda and Modern science between the age below 45 years,that patients should be effected to falling hair more than 100 strands per day, were randomly selected for the clinical study irrespective of sex, religion, and habitat etc.

The patient who can follow the given instructions thoroughly will be included to this study.

\section{Exclusion Criteria:}

- Patients whose age limit above 45 years.

- Patients having hereditary history of baldness.

- Patients having history of hair loss due to injury.

- Patients who are using artificial dyes, shampoos, Gels etc.

- Patients suffering from any severe systemic disease.

- Patients who have been diagnosed to have local disease like Alopecia areata, Alopecia totalis, Tinea capitis, Folliculitis decalvans and in Ayurvedic terms patients of Arunshinka, Indralupta.

Before the treatment, the procedure was explained to the patients and got their consent. Patients were examined and recorded their history in the Performa which prepared including all the necessary aspects of Ayurveda and modern medical science. The patients were advised to give gentle massage to the scalp covering whole area with hair oil at night and rinse it in the morning for one month.

\section{Assessment Criteria:}

The clinical condition was assessed before and after two weeks, after four weeks treatments and after follow up period.

\section{Subjective Criteria:}

Signs and associated symptoms ${ }^{[3,4,5]}$ were assessed by using grading system.

1) Hair fall

$$
\text { Absent }-0
$$


Mild (hair fall on washing) - 1

Moderate (hair fall on combing) - 2

Severe (hair fall on simple strengthening) -3

2) Darunaka

3) Kandu

4) Kesha Rukshatwa

5) Kesha Katinya

6) Kesha Tanutwa

7) Kesha Bhoomi Daha

8) Kesha Bhoomi Durganda

for above symptoms same gradation system was applied.

\section{Total Treatment assessment:}

- Complete Remission : $100 \%$ relief

- Marked Improvement : More than 75\% improvement

- Moderate Improvement : 50\% to 75\% improvement

- Mild Improvement : $25 \%$ to $49 \%$ improvement

- Unchanged : Less than $25 \%$ reduction

\section{Follow up:}

Patients were followed for one month after the treatment.

\section{Results and Discussions}

Among the sixty patients, 23 patients (38.33\%) were male and 37 patients (61.66\%) were female. But the previous researches show that the males are more prone to loss hair than the females .They shows one out of three men is affected by the hair loss associated with testosterone, the principle male sex hormone. In present study most of patients were female it may be because they are most concerning about the problem and move to the treatments.

When selecting representative sample, the patient's age was considered. Patients those who were more than 45 years excluded, because it is a physiological phenomenon in human aging process, generally after the mid-forties. There were 15 patients represent $25 \%$ with total sample size at age group was in between 15-24 age. There were 35 patients (58.33\%) in age 25-34 group and 10 patients $16.66 \%$ ) in $35-45$ age group.

While analyzing causative factors, it was found that maximum numberof patients (46\%) were having emotional stress followed by overstyling in $43.33 \%$ patients. Then $38.33 \%$ of patients suffered from malnutrition, $26.66 \%$ patients were having other medical conditions such as thyroid problems, hormonal imbalance, scalp infections, skin disorders, Grahani, Vibhanda, Amlapitta, Peenasa etc. According to basic calculation, 23.33\% patients were getting medication such as Antidepressants,blood thinners, NSAIDS, anabolic steroids, birth control pills etc. As well as $12 \%$ patients were having heredity and $10 \%$ were having physical stress. Eight signs and symptoms were assessed under the present clinical study. All the patients have shown the symptom of hair falling. Then $70 \%$ were having Darunaka followed by Kesha Bhoomi Daha in $61.66 \%$ patients, $60 \%$ patients were having Kesha Rukshatwa, $56.66 \%$ patients having Kandu, 
48.33\% were having Kesha Katinya, 33.33\%were having Kesha Tanutwa and $31.66 \%$ were having Kesha Durganda.

Table 1: Wilcoxon signed-rank measurement table

\begin{tabular}{|c|c|c|c|c|}
\hline & & $\overline{\mathbf{N}}$ & Mean Rank & Sum of Ranks \\
\hline \multirow[t]{4}{*}{ Hair fall(After) - Hair Fall(Before) } & Negative Ranks & $51^{\mathrm{a}}$ & 26.78 & 1366.00 \\
\hline & Positive Ranks & $1^{\mathrm{b}}$ & 12.00 & 12.00 \\
\hline & Ties & $8^{c}$ & & \\
\hline & Total & 60 & & \\
\hline \multirow{4}{*}{$\begin{array}{l}\text { Darunaka(After) } \\
\text { Darunaka(Before) }\end{array}$} & - Negative Ranks & $38^{\mathrm{d}}$ & 21.59 & 820.50 \\
\hline & Positive Ranks & $3^{e}$ & 13.50 & 40.50 \\
\hline & Ties & $19^{\mathrm{f}}$ & & \\
\hline & Total & 60 & & \\
\hline \multirow[t]{4}{*}{ Kandu(After) - Kandu(Before) } & Negative Ranks & $25^{\mathrm{g}}$ & 14.24 & 356.00 \\
\hline & Positive Ranks & $2^{\mathrm{h}}$ & 11.00 & 22.00 \\
\hline & Ties & $33^{i}$ & & \\
\hline & Total & 60 & & \\
\hline \multirow{4}{*}{$\begin{array}{l}\text { Kesha Rukshatwa(After) } \\
\text { Rukshatwa(Before) }\end{array}$} & $a$ Negative Ranks & $31^{\mathrm{j}}$ & 16.00 & 496.00 \\
\hline & Positive Ranks & $0^{\mathrm{k}}$ & .00 & .00 \\
\hline & Ties & $29^{1}$ & & \\
\hline & Total & 60 & & \\
\hline \multirow{4}{*}{$\begin{array}{l}\text { Kesha } \quad \text { Katinya(After) } \\
\text { Katinya(Before) }\end{array}$} & $a$ Negative Ranks & $25^{\mathrm{m}}$ & 13.00 & 325.00 \\
\hline & Positive Ranks & $0^{\mathrm{n}}$ & .00 & .00 \\
\hline & Ties & $35^{\circ}$ & & \\
\hline & Total & 60 & & \\
\hline \multirow{4}{*}{$\begin{array}{l}\text { Kesha Tanutwa(After) } \\
\text { Tanutwa(Before) }\end{array}$} & $a$ Negative Ranks & $16^{\mathrm{p}}$ & 8.50 & 136.00 \\
\hline & Positive Ranks & $0^{\mathrm{q}}$ & .00 & .00 \\
\hline & Ties & $44^{\mathrm{r}}$ & & \\
\hline & Total & 60 & & \\
\hline \multirow{4}{*}{$\begin{array}{l}\text { Kesha Bhoomi Daha(After) } \\
\text { Kesha Bhoomi Daha(Before) }\end{array}$} & - Negative Ranks & $32^{\mathrm{s}}$ & 16.50 & 528.00 \\
\hline & Positive Ranks & $0^{t}$ & .00 & .00 \\
\hline & Ties & $28^{\mathrm{u}}$ & & \\
\hline & Total & 60 & & \\
\hline \multirow{4}{*}{$\begin{array}{l}\text { Kesha Bhoomi Durganda(After) } \\
\text { Kesha Bhoomi Durganda(Before) }\end{array}$} & - Negative Ranks & $16^{v}$ & 9.09 & 145.50 \\
\hline & Positive Ranks & $1^{\mathrm{w}}$ & 7.50 & 7.50 \\
\hline & Ties & $43^{x}$ & & \\
\hline & Total & 60 & & \\
\hline
\end{tabular}


According to table 01, there was higher frequency for negative ranked value (51) for hair fall symptom. It generated that after treatments, there was reduction in hair fall when compare to lower frequency for positive ranked value (1). So there was around 1300 value obtained as sum of negative ranked category which was higher compared to positive sum of ranked value (12). It indicated that there was higher portion represented to negative ranked category which had more potential compared than positive ranked category.

When considering Dharunaka, $50 \%$ of patients were cured by this treatment compared with the frequencies of negative ranked value (38) and positive ranked value (19).

Kandu has no comparative higher sum of ranks deviation with negative value (356) and positive value (22), because it had higher frequency value for tied ranks (33).

Other symptoms have zero frequencies for positive ranks values. Among them, Kesha Boomi Daha had higher mean rank value (16.5) next to Kesha Rukshtwa (16). Low mean ranks value (8.5) was obtained to Kesha Thanutwa which would no impact on this treatment.

Table 2: Wilcoxon signed-rank test table

\begin{tabular}{|c|c|c|c|c|}
\hline & $\mathbf{Z}$ & Asymp. Sig. (2-tailed) \\
\hline \multicolumn{3}{|c|}{ Hair fall(After) - Hair Fall(Before) } & $-6.268^{a}$ & .000 \\
\hline \multicolumn{3}{|c|}{ Darunaka(After) - Darunaka(Before) } & $-5.233^{\mathrm{a}}$ & .000 \\
\hline \multicolumn{3}{|l|}{ Kandu(After) - Kandu(Before) } & $-4.257^{\mathrm{a}}$ & .000 \\
\hline \multicolumn{3}{|c|}{ Rukshatwa(Before) } & $-5.200^{\mathrm{a}}$ & .000 \\
\hline $\begin{array}{l}\text { Keshar Katinya(After) } \\
\text { Katinya(Before) }\end{array}$ & - & Kesha & $-4.620^{\mathrm{a}}$ & .000 \\
\hline $\begin{array}{l}\text { Kesha Tanutwa(After) } \\
\text { Tanutwa(Before) }\end{array}$ & - & Kesha & $-3.640^{\mathrm{a}}$ & .000 \\
\hline \multicolumn{3}{|c|}{$\begin{array}{l}\text { Kesha Bhoomi Daha(After) - Kesha Bhoomi } \\
\text { Daha(Before) }\end{array}$} & $-5.090^{\mathrm{a}}$ & .000 \\
\hline \multicolumn{3}{|c|}{$\begin{array}{l}\text { Kesha Bhoomi Durganda(After) - Kesha } \\
\text { Bhoomi Durganda(Before) }\end{array}$} & $-3.499^{\mathrm{a}}$ & .000 \\
\hline
\end{tabular}

a. Based on positive ranks.

b. Wilcoxon Signed Ranks Test

Table 02, explained that when considering Wilcoxon signed ranked test, there were different median values obtained to before treatments and after treatments at $95 \%$ confidence. Corresponded all P values (0) were less than 0.05 level of error. Finally, the hair oil effectiveness had greater success by observing those eight symptoms at $5 \%$ level of error. 


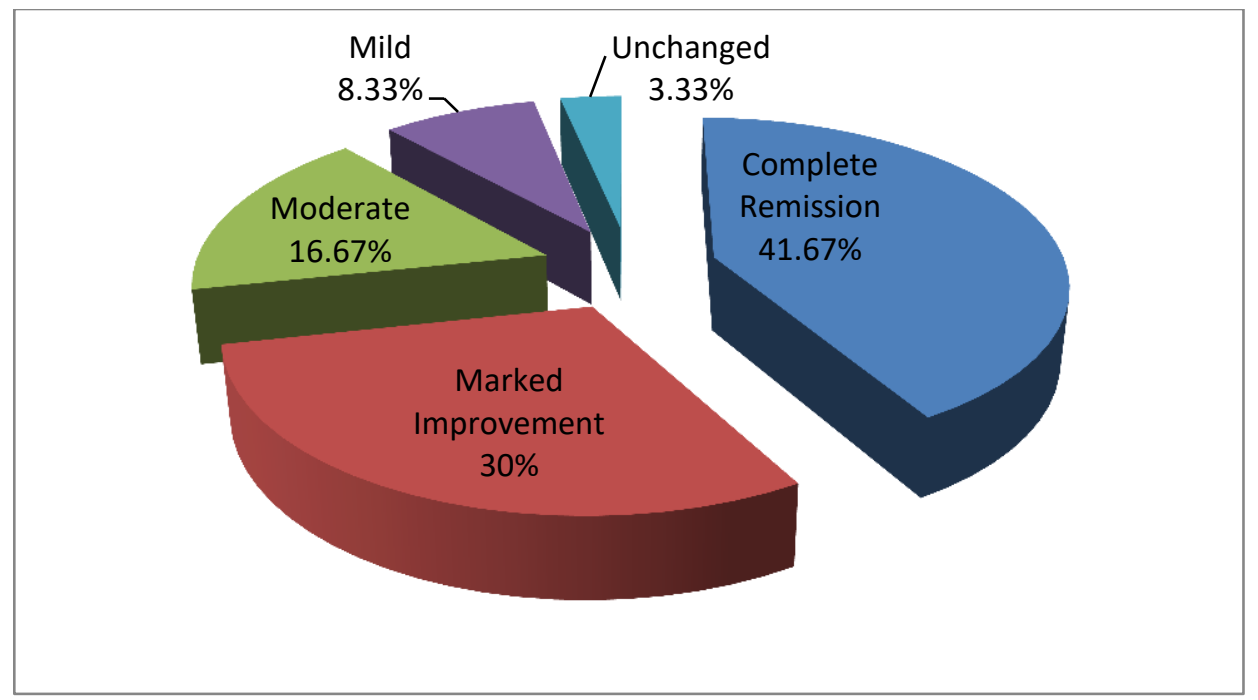

Figure 1: Total treatment assessment

Figure 1 illustrated that there was decreasing percentage values occurred through total treatment assessment segment wise respectively. It indicates that total treatment assessment characteristics had ranked pattern. So, there was higher percentage value $(80 \%)$ obtained by combining complete remission, marked improvement and moderate improvement portions.

\section{Conclusions \& Recommendations}

It can be concluded that the treatment modality, applying Kashmaryadi thila is successful in reducing hair falling and other corresponded symptoms. So, it is very beneficial in managing Kalitya.

It would be the probable mode of action, Kashmaryadi oil having Keshya, Rasayana, Vata pitta samana guna etc may success in correcting the pathophysiology of kalitya.

\section{References}

[1] Tankan R, Patil V and, Aithal P. Clinical Study On Different Procedures of Nasya With BhringarajaTaila In Khalitya (Alopecia) Journal of Ayurveda and Holistic Medicine (JAHM) (ISSN:2321-1563) Vol 2, No 4 (2014)

[2] Garde GK, Ambedkar D (Editor), SarthVagbhat(Vagbhathrut Ashtanghridaya Marathi Translation). Uttarstana Chp 24/ 24-28; Aaryabhushan Mudranalaya; 1970 p.426.

[3] Nagraj Goutam,RaghuwanshiNagendra Singh, Kumari Madhur, A clinical study to establish the principle "nasa hi shirsodwaram" with special reference to nasya in khalitya, Research Article International Ayurvedic Medical Journal ISSN:2320 5091

[4] Prof. Srikantha Murthy K.R , Susruta Samhita , Vol 1,2, Chaukhambha Orientalia , Varanasi , India , 1962

[5] Prof. Srikantha Murthy K.R , Astanga Hrdaya Samhita , Vol 3 , Reprint , Chowkhamba Krishandas Academy, Varanasi , India , 2005

*Corresponding author.

E-mail address: pramodani@ayu.lk 